\title{
Does Labour Law Have a Future?
}

\section{Introduction}

Yf we are to provide an answer to the provocative question posed

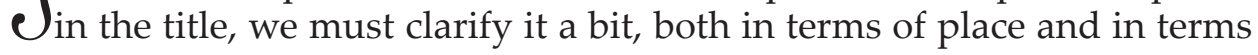
of time. From the perspective of locale we will focus on continental Europe, to which the Czech Republic and Poland belong geographically. In terms of time we will consider a span of decades or at most several centuries, because it would be excessively presumptuous to predict any longer span of time. In such considerations we must also necessarily delve into the past, because from what else can we attempt to anticipate the future than from the past?

\section{Historical Background}

The historical roots of labour law are practically as old as law itself. At the time when state power and the need for legal regulation were arising, the need for legal regulation of the work of free citizens who hired themselves out also arose. Although historically the majority of societies were long based on work performed by the unfree (at first slaves, later serfs), the need to legally regulate the work of free "wage labourers" led to the formulation of legislation on such relationships. Very well known from Roman law is the wage (or employment) contract locatio conductio operarum.

The fact that Roman law made provisions for locatio conductio operarum can certainly not lead to any theories on the existence of "Roman labour law". This contract was merely one of a number of types of private law contract. For long centuries, including the civil law codifications

* Prof. JUDr., Charles University Faculty of Law, Prague. 
at the turn of the nineteenth century, the employment contract continued to remain one of the numerous contractual institutions of civil law. We consider it indisputable that civil law arose historically as a branch including all of private law, just as it is undeniable that it continues to form its foundation to date. Only over the course of the $19^{\text {th }}$ century did certain contractual institutions, until that time part of a unified civil law, start to exhibit greater or lesser specific characteristics that required certain specific legal treatment. For some categories of legal relationships the tendency thus gradually arose to become relatively independent branches of law emerging from the womb of civil law. This was not only true of labour law, but also of commercial law and international private law.

There is no doubt that for the territory of today's Czech Republic, the most important standard governing employment relationships was the General Civil Code declared by Patent of 1 June 1811, No 946 Z.S. The act of 28 October 1918, No 11 Z.a.n. on the establishing of an independent Czechoslovak state, which is traditionally called the reception act, states in Art. 2 that all existing provincial and imperial laws and regulations shall remain valid for the time being. The Czechoslovak Labour Code thus came to include the Civil Code from 1811, which starting 28 October 1918 applied as the "Czechoslovak General Civil Act".

112 Emancipation of labour law from civil law took place at two levels in roughly the second half of the $19^{\text {th }}$ century. The first level consisted of "protective" or "social" legislation, whereby the state, through its legislative acts, began to restrict the contractual freedom not only in concluding an employment contract, but especially during the course of the employment. Contractual freedom was restricted in favour of one party - the employee. Public elements began to increasingly infiltrate the field of labour law, which until then had been exclusively the domain of private law.

The second area in which the emancipation of labour law took place was the field of collective bargaining and the emergence of collective labour law. Thus collectivist elements invaded the purely individual sphere that is typical for the field of civil law, and in continental law a new source of law arose in collective agreements.

Although we can date the birth of labour law in the modern sense of the word, as stated above, to roughly the mid- $19^{\text {th }}$ century (whether the beginning, middle or second half of the century varies from country to country) and labour law is thus more than one hundred fifty years old, debate on its relationship to civil law has not died down.

It must be admitted that if emancipation and the specifics of labour law as separate from civil law are still being discussed at the European and global level, it does not attest to the "strength" of labour law, or to a clear and stable view of this legal branch. Labour law sometimes 
"obstructs" employers with its protective laws and restrictions on contractual freedom in favour of the employee. At various stages of historical development and in various countries there have been repeated attempts to circumvent labour law or at least partially reduce its protective function. Labour relationships that do not enjoy the same protection as standard employment are sought out, and these relationships are referred to as "precarious employment". This problem resurfaces again and again in periods of economic stagnation and recession and discussions on a crisis of labour law repeatedly appear.

In the Czech Republic the problem of the relationship between civil and labour law is even more sensitive due to the historical developments after 1948. The directly run economy did not allow freedom of contract or provide space for collective bargaining. In addition, this ideological concept was based on the premise that work is not goods, thus work activity cannot be governed by civil law. This led to the codifications of the 1960s and, as part of them, the Labour Code adopted in 1965 which, although it meant the codification of labour legislation, brought about a complete break between labour law and civil law. This extreme of separating labour law from civil law was not however carried out in all the former eastern and central European countries by far. The codification of labour law in the form in which it was executed in the former Czechoslovakia meant regulation of all the general institutions in the Labour Code (in many cases the Civil Code was simply paraphrased) and the subsidiary use of the Civil Code for labour relations was also ruled out. In this manner the relationship between civil and labour law was artificially deformed and, in addition, the Labour Code was conceptually built as a mandatory standard that nearly fully ruled out contractual bargaining (both individual and collective) and did not allow contractual freedom.

Attesting to the fact that the issue of labour law and civil law and the relationship between them is still highly current in the European and worldwide context as well are the topics of European and global congresses organised by the International Society for Labour and Social Security Law in the last decades. One such example is the topic of the round table at the European Congress of Labour Law and Social Security, which was organised in September of 1996 in Leiden, Netherlands under the title "Emancipation of Labour Law from Civil Law". Likewise, the second of the three main topics at the World Congress of Labour Law and Social Security that took place in September 2000 in Jerusalem was "Similarities and differences between labour contracts and civil and commercial contracts".

An essential difference between labour and civil (as well as commercial) law consists of public intervention in contractual relationships, which leads to significant restriction on contractual freedom. This was 
the principle of the protective legislation of the 19th century, when the state provided protection for the economically weaker partner in the contractual relationship, i.e. the employee, and this basic principle has remained characteristic for labour law in the twenty-first century as well. Public intervention thus significantly limits the freedom of contract between the parties, i.e. between employers and employees. Of course it can be argued that we also encounter restrictions on contractual freedom in civil law, in fact quite considerable restrictions in some types of contract (typically for example a rental agreement for an apartment). The extent of restriction on contractual freedom in labour is however incomparable to any other area of private law and is of such intensity that it constitutes one of the fundamental principles on which labour law is based. This restriction pervades practically the whole treatment of the employment relationship. In particular this includes mandatory minimum working conditions that must be observed by the other party, i.e. the employer, and which cannot be agreed upon as any less favourable for the employee than is laid down by the law. By way of example we can mention scheduling of working hours and the maximum scope thereof (including the maximum scope of overtime work), minimum rest period (both within a shift and the minimum rest between shifts and uninterrupted rest in the week, as well

114 as the minimum scope of rest leave) and protection of wages and the minimum amount thereof. The extensive provisions on workplace health and safety also dictate the conditions under which an employer cannot employ an employee at all. A category to itself is the treatment of terminating employment, which protects the "weaker party", i.e. the employee, from termination.

Contractual freedom in labour law is not limited only to public, primarily legislative, regulation however. In employment, individual contractual freedom is also limited by the collective will, i.e. collective agreements. This is a further fundamental difference from any private law. This restriction, i.e. subordination of individual freedom of contract to another (collective) agreement is a typical and characteristic feature of labour legislation distinguishing it from civil law. We can date the birth of this characteristic element of labour law back to the $19^{\text {th }}$ century and it has lost no power or distinctness at the start of the twenty-first century. In general it is true that less favourable salary and working conditions cannot be agreed upon in an individual employment contract than those laid down by the collective agreement. This is thus a marked limitation on the freedom of contract in negotiating individual employment contracts, once again in favour of the "weaker party", i.e. the employee.

Restriction of freedom of contract in favour of the employee is a typical characteristic trait of labour law, not only in Europe but around the world. 
In general it can also be said that in all countries this limitation of freedom of contract occurs both through legislation and collective agreements. However, the intensity of protection of employees, i.e. the level of interference with freedom of contract, naturally varies in different countries.

\section{International Context}

It is doubtless that Czech labour law has, just as is the case in other central European countries (we are thinking especially of Poland, Slovakia and Hungary), been strongly influenced by the law of the European Communities, particularly since the end of the 1990s. The most significant change to Czech labour law related to the European Union took place before the Czech Republic's accession through the harmonisation amendment to the Labour Code No 155/2000 Coll., which harmonised Czech labour law with dozens of EU directives and affected many dozens of provisions of the existing Labour Code. A milestone was naturally 1 May 2004 - the day the Czech Republic joined the EU. The harmonisation process continued before accession and after it the implementation process has continued to run, bringing further changes to Czech labour law with regard to the law of the European Communities. The influencing and changing of Czech labour law in this manner does not impact the whole labour law system evenly. There are institutions that have undergone far-reaching changes as a result of accession to the EU, such as the fields of equal treatment and non-discrimination, working hours, rest periods, and workplace health and safety. In contrast there are areas of Czech labour law, such as liability for damages, where no significant changes associated with the law of the European Communities have taken place.

The keyword for labour law, not just in the Czech and European context, but worldwide, is becoming liberalisation and above all "flexibility". Thus it is no coincidence that at the XVIII World Congress of Labour Law and Social Security, which took place in September 2006 in Paris, the first topic for discussion was "Trade liberalisation and labour law". Whether it wants to or not, labour law will have to respect the globalisation and liberalisation of the global economy, which brings with it further demands on flexibility of the legal treatment. Greater flexibility is the keyword for the worldwide trend in labour law. Global international competition leads in general to attempts to reduce the labour law protection of employees.

The European Union is also aware of the worldwide trend toward the need for certain liberalisation as a result of changes in needs and general interests, as follows from the Council of the EU's "Green Paper 
of 23 November 2006; Modernising labour law to meet the challenges of the $21^{\text {st }}$ century", according to which greater flexibility should be incorporated into labour law while maintaining basic protection of employee rights. (The Green Paper is available at: http:/ec.europa.eu/employmentsocial/labourlaw/greenpaperen.htm). The Green Paper is based on the fact that European labour markets face the challenge of combining greater flexibility with the need to maximise security for all.

The effort to find a balance between "flexibility" of labour law and its protective function (including a certain degree of security for employees) is of course nothing new. Labour law has been grappling with this essentially since its inception. As is well known, internationally speaking the labour law of European countries is without a doubt considered the "most social", providing the greatest security to employees.

The problem of the newly acceded EU countries from the former communist Eastern Bloc (the Czech Republic being a typical example) is the additional fact that the original "socialist" labour codes in these countries were naturally anti-liberal and imperative. The European Union, in its directives governing labour law which have been implemented into our labour legislation, likewise restrict freedom of contract of the parties in an employment relationship. In addition, this treatment tends

116 strongly toward casuistry. Here however it is necessary to realise the fundamental difference between the "old" EU member states and those such as the Czech Republic. In the "old member states" of the EU, liberal regulation of the employment market was in place, into which the European Union started to gradually interfere with its directives. This means that the overall liberality of the labour legislation was merely modified by transposition of directives. In the Czech Republic, on the other hand, the anti-liberal legislation was strengthened even further by transposition of directives. If we become aware of the current scope of European Union directives in the field of labour law, it is evident that harmonisation of our labour legislation with EU law has not contributed to the flexibility of our labour law, but has done quite the opposite.

\section{Current developments in the Czech Republic}

From what has been stated above it is clear that ties to civil law also comprised one of the most critical issues discussed in preparing the new private law and labour law codification in the Czech Republic. Unfortunately the result was the new Labour Code from 2006 (Act No 262/2006 Coll.), which dealt with the relationship between the Civil Code and Labour Code not based on the principle of subsidiarity, but of delegation. 
In this context it should be noted that, with the exception of the legal treatment in several former communist countries, both the historical and contemporary legislation in European countries stem from a relationship between civil code and labour legislation based on subsidiarity. This concept is traditional, proven in practice - today not just by decades but by a century of practice - and does not give rise to any doubts. The new Labour Code was based on conceptually new (and thus not proven by experience and practice) ties between civil law and labour law, and this fact alone invites doubts about its implementation and future application. The principle of delegation has certainly exposed the new Labour Code to greater instability in terms of future (new) private law legislation than the principle of subsidiarity would have. Unfortunately the legal treatment was not returned "to its original state" and - instead of the traditional relationship of subsidiarity - the unfortunate concept of delegation was chosen.

The concept of delegation was attacked with a proposal to repeal Section 4 submitted to the Constitutional Court by a group of MPs. The submitters argued that the concept of delegation of the Civil Code used by the new Labour Code established legal uncertainty and brings about considerable application problems as a result of the unfamiliarity and ambiguity of the legal norms; it contravenes the principle of "quality of law" and also undermines confidence in the law. Problems in application may arise as a result of the co-existence of two otherwise unrelated and non-corresponding provisions of the new Labour Code and the Civil Code, which must also be applied at the same time (not in subsidiarity) as a result of the (mandatory) reference of the new Labour Code.

The Constitution Court (Judgment No 116/2008 Coll.) agreed with the submitters' objection to the principle of delegation. In the grounds of the judgment the Constitutional Court did not find the principle of delegation, as enshrined in relation to the Civil Code, to be in harmony with the principles of the rule of law. The Constitutional Court emphasised that the principle is that civil law is the general private law (i.e. that the Civil Code is a general private law regulation) with subsidiary application to other private law branches. The regulations governing these branches have priority in principle, but if they do not address a certain issue, the general civil legislation shall apply.

The new Civil Code (Act No 89/2012 Coll.) in Section 2401 more or less merely states and fully respects the historical tie between labour law and the Civil Code, with the Civil Code being the general standard for all of private law, including labour law. This principle is now indeed included in the Labour Code itself which, in its revised Section 4 (adopted following the Constitutional Court ruling), states that labour law relationships shall be governed by the Labour Code, but if it cannot be applied, they shall be 
governed by the Civil Code, always in accordance with the basic principles of labour law relationships. On the other hand, the Civil Code fully respects the autonomy of labour law and leaves the treatment of labour relationships and in general the whole area of labour law to specific acts, in particular the Labour Code. Thus we currently have two legal codes in private law, the Civil Code and the Labour Code.

It follows from the second sentence of Section 2401 (1) of the Civil Code that it leaves not just employment, including the rights and obligations of the employee and employer arising from employment, to another act, but it also leaves the whole field of employment work to specific legislation. Other agreements on the performance of employed work establish a similar commitment between employee and employer, above all the agreement on work activity and agreement on execution of work, dealt with in the third part of the Labour Code. Employment and these two kinds of agreement are considered the basic labour law relationships. In Section 3, the Labour Code assumes that dependent work can essentially only be performed in a basic labour law relationship, but it does allow that it can also be performed in relationships governed by laws that have the nature of specific legislation in relation to the Labour Code. A typical example of such a law is the Civil Service Act.

\section{Conclusion}

Labour law in the modern sense of the word is nearly 200 years old. In that time it has naturally changed significantly, but its foundation has remained the same. This includes the interference of lawmakers restricting freedom of contract in the interest of protecting one party, the employee, and also collective bargaining, which leads to the conclusion of collective agreements. There have been changes to the nature of work, working conditions and often even the place where work is performed, which is becoming less and less dependent on the employer's workplace or manufacturing facility. Nevertheless the essence of labour law has not changed. On the contrary it could be said that change is more prevalent in civil law, which was always based on freedom of contract and the equal position of the parties, and which is increasingly being encroached upon by the element of protecting the weaker party. This is the case in European countries in large part due to EU law, which is typically encountered in consumer contracts, for example.

We dare to express the conviction that, although from time to time one can read about a crisis of labour law or a crisis of the union movement, and thus a crisis of collective bargaining, labour law nevertheless has a fu- 
ture for at least the coming decades. Even though the nature of work will continue to change and people will increasingly do business independently or as freelancers and the organisation of trade unions will likely continue to fall, we must count on labour law continuing to exist. Its sources shall continue to be labour legislation based on the fundamental principle of protecting the position of employees and collective bargaining.

\section{Czy prawo pracy ma przyszłość?}

\section{Streszczenie}

Jeśli mamy odpowiedzieć na prowokujące pytanie zawarte w tytule, musimy sprecyzować je co do miejsca i czasu. Z perspektywy miejsca musimy skoncentrować się na kontynentalnej Europie, do której geograficznie należą Republika Czeska i Polska.

Prawo pracy $\mathrm{w}$ nowoczesnym rozumieniu ma prawie 200 lat. $\mathrm{W}$ tym czasie, co naturalne, zmieniło się znacznie, lecz jego podstawa pozostała ta sama. Obejmuje ona ingerencję twórców prawa w wolność umów w celu ochrony pracownika oraz rokowania zbiorowe, prowadzące do zawierania umów zbiorowych.

Ośmielamy się wyrazić przekonanie, że choć od czasu do czasu można przeczytać o kryzysie prawa pracy lub o kryzysie ruchu związkowego, a w rezultacie o kryzysie rokowań zbiorowych, prawo pracy ma nadal przyszłość, co najmniej w nadchodzących dekadach. Musimy polegać na prawie pracy, niezależnie od postępujących zmian w naturze pracy, zwiększania się sfery niezależnego biznesu i pracy niezależnej oraz spadku organizowania się w związki zawodowe. Jego źródłem pozostanie ustawodawstwo pracy oparte na fundamentalnej zasadzie ochrony pracowników i na rokowaniach zbiorowych. 